at Gettysburg. He would like to hear members, who were there, state their experience in regard to it.

Dr. Whiston stated that such had been the case. He considered coal oil as a very good disinfectant and deodorizer. In cleanses the wound well, and kecps away flies and vermin; it causes no disagreeable sensation to the patient. In regard to sutures, he had scen at Gettysburg two cases of amputation of the thigh, in which the silver suture was used, unite by first intention.

Dr. CaLHoun greatly preferred the silver suture; it saves time, being readily applied, and is more easily removed. In a recent operation for phymosis, he had, by means of the silver suture, obtaincd union by first intention throughout.

Dr. KING referred to irrigation of wounded parts by means of a siphon, as requiring constant attention and supervision; it is a most powerful method of applying cold, and unless great care is exercised the vitality of the parts may be lowered to an injurious extent, and the death of the flap may follow. He had seen one instance in which injury had been caused in this way.

Dr. CalHoun, in calling attention to the importance of keeping the cavities of wounds well cleaned, cited a paper lately published by Dr. J. B. Smith, on resections and amputations, in which Dr. Smith states the good results of introducing a small catheter into the cavity of the wound, to drain it of the offensive pus. In resections of the shoulder, this is of special importance.

Dr. Hovgr related a case of amputation of both legs in a young man, in which both stumps healed by first intention.

At a meeting of the Medical Society of the Surgeons of the $2 \mathrm{~d}$ Division, 3d Corps, Army of the Potomac, held March 2d, it was voted, "that the essay read by Dr. Jewett, with a report of the discussion following, be forwarded by him to some medical journal for publication."

\title{
DEATH FOLLOWING THE EXCISION OF A NAVUS.
}

By Samuel Canot, M.D., Surgeon to Mass. Gen. Hospital.

[Read before the Boston Soclety for Medical Improvement, March 14th, 1804, and cotnmunicated for tho J3oston Medical and Surgical Journal.]

March 8th.-A child 7 months and a few days old was brought to my office for advice, in reference to a vascular tumor (raspberry), situated on the right side of the os frontis, at some distance in front of the coronal suture. As it was increasing rapidly in size, I advised that it should be removed at once, and as it was situated over a smooth bony surface, favorable for the easy arrest of blecding, I decided to excise, rather than to apply ligature. Assisted by my neighbor, Dr. J. C. White, who kindly attended to the etherization, I cut out the 
tumor by two semilunar incisions, extending through the scalp. There was but little blecding, about an ounce-certainly not two ounces of blood were lost; two small vessels were tied, and the sides of the wound were brought together by interrupted silk sutures. $\Lambda$ compress and bandage were applied, and the operation terminated. It took but a short time, and Dr. White says that not more than an ounce of ether was used.

I was obliged to leave my house as soon as the operation was finished, and did not return till after the patient had gone. I told the father of the child to call in a physician and have the stitches removed on the second day.

I should have thought no more about the case, as nothing about it gave any ground for anxicty, if I had not received, on the 14th, a Jetter from Dr. A. LcB. Monroe, dated 11th, saying, "The child fiom whose head you removed an erectile tumor last T'uesday, died the next day. I was called the next morning. Pulse very weak and frequent, skin cool, pupils dilated, conjunctivæ injected. At 3, P.M., pulse imperceptible, pupils more dilated, and unaffected by a strong light, respiration slow and difficult; died an hour or so after.

"This morning made a post-mortem examination. Upon reflecting the scalp, the intervening cellular tissue was found infiltrated with blood, fiom an inch or more forward of the wound, back over the occiput to the nape of the neck. The track of blood varied from one to two inches in width. Upon removing the calvarium, the vessels of the brain were seen unusually distended, and the brain itself rather softer than wo usually find it without discase. The mother says the child never recovered perfect consciousness; it nursed once on the way home, and once afterwards. About 12, P.M., it vomited, and after until 2, A.M." Dr. M. in a subsequent letter says, "The ligatures you applied remained firm, and I found no artery unligated." Dr. M. told me afterward that there had been no escape of blood externally, the dressings were unstained.

On reviewing this case, we find a healthy child, after an operation involving a small surface of the head (the wound when closed not being more than an inch in length), accompanicd by very moderate loss of blood and small degree of etherization, remains in a state of partial unconsciousness for twelve hours, then it is seized with vomiting, which lasts for two hours, followed by collapse and death in twclve hours more-the whole time from the operation to the death being about twenty-six hours.

\section{TINCTURE OF ACONITE IN VARIOLA.}

By Josepir W. Crift, Act. Assist. Sura. U.S.A., Artillery Birg., Gth Corps.

[Communicated for the Boston Medical and Surgical Journul.]

IN common with many other portions of this Army, this command has been visited the past scason with smallpox. Jan. 10th, 1864, 